\title{
Study of endometrial histopathology in women with abnormal uterine bleeding
}

\section{Ushadevi Gopalan*, Sathiyakala Rajendiran, Ranganathan Karnaboopathy}

\begin{abstract}
Department of Obstetrics and Gynecology, Shri Sathya Sai Medical College and Research Institute, Ammapettai village, Kancheepuram District, Tamilnadu, India
\end{abstract}

Received: 17 January 2017

Accepted: 27 January 2017

\section{*Correspondence:}

Dr. Ushadevi Gopalan,

E-mail: ushag7@hotmail.com

Copyright: $($ ) the author(s), publisher and licensee Medip Academy. This is an open-access article distributed under the terms of the Creative Commons Attribution Non-Commercial License, which permits unrestricted non-commercial use, distribution, and reproduction in any medium, provided the original work is properly cited.

\begin{abstract}
Background: Abnormal uterine bleeding is a major gynaecological problem accounting for $33 \%$ of Gynaec outpatients. The cause of the bleeding is established in only $50-60 \%$ of the cases. The aim of this study was to evaluate the various histopathological patterns in the endometrial biopsy of patients presenting with abnormal uterine bleeding and to determine the specific pathology in the different age groups.

Methods: This was a prospective study done in a tertiary care teaching hospital for a period of 2 years. Total of 905 patients with abnormal uterine bleeding were included in the study and they were subjected to a Dilatation and Curettage. Histopathological examination of the endometrial biopsy was done and the various histopathological patterns identified and classified.

Results: The age of patients ranged from $24-74$ years. $54.7 \%$ were in the age group 40-49 years followed by $23.4 \%$ in the age group 30-39 years. The most frequent findings were proliferative findings in $47.3 \%$ followed by secretory endometrium in $16.1 \%$ patients. Proliferative endometrium was more common in the age group 40-49 years as also disordered proliferation, secretory endometrium, cystoglandular hyperplasia and endometrial hyperplasia.

Conclusions: Endometrial curettings and biopsy is an important diagnostic procedure for assessing all cases of abnormal uterine bleeding and to plan for successful management.
\end{abstract}

Keywords: Fetal distress, Hypertension in pregnancy, Stillbirths

\section{INTRODUCTION}

Abnormal Uterine Bleeding is defined as changes in frequency of menstruation, duration of flow or amount of blood loss. ${ }^{1}$ It is a major gynaecological problem accounting for $33 \%$ of out patient referrals, including $69 \%$ of referrals in perimenopausal and postmenopausal age group. ${ }^{2}$ This has negative impact on women's health and wellbeing including anemia, impacting their quality of life by impairing sexuality and leads to absenteeism and social embarrassment. Non-structural abnormal uterine bleeding or the formerly called dysfunctional menometrorrhagia is a frequent cause of abnormal uterine bleeding. ${ }^{3}$ Because of its broad range of differential diagnosis, the diagnosis of abnormal uterine bleeding can be quite challenging. Despite a detailed history, various blood investigations and a thorough physical examination including transvaginal ultrasound, the cause of the bleeding is established in only $50-60 \%$ of the cases. ${ }^{4}$ The causes of Abnormal uterine bleeding may be physiological, pathological or pharmacological. ${ }^{5}$ It has been shown to be associated with almost any type of endometrium ranging from normal endometrium to hyperplasia, irregular ripening, chronic menstrual irregular shedding and atrophy. ${ }^{6}$ The manifestation of various disease patterns can be detected by histological variations of the endometrium taking into account the age of the woman, the phase of her menstrual cycle and iatrogenic use of hormones. The Evaluation of endometrial biopsy requires understanding of important 
clinical questions, realistic expectations, systematic and practical approach. The clinical expectations for each group are unique as are morphological patterns most commonly encountered. ${ }^{7}$ Abnormal perimenopausal or postmenopausal bleeding is associated with endometrial cancer in approximately $10 \%$ of cases. Atypical endometrial hyperplasia is felt to be a precursor of endometrial cancer and may progress over time to endometrial cancer in 5-25\% of patients. In addition, atypical endometrial hyperplasia is associated with a coexisting endometrial cancer in approximately $20 \%$ of patients. ${ }^{8}$ The sensitivity of endometrial biopsy for the detection of endometrial abnormalities has been reported to be as high as $96 \% .^{9}$ However, this office based procedure misses up to $18 \%$ of focal lesions, including polyps and fibroids because only a small part of the endometrium may be sampled at one time. ${ }^{10}$ Although endometrial biopsy has high sensitivity for endometrial carcinoma, its sensitivity for detecting atypical endometrial hyperplasia may be as low as $81 \% .^{11,12}$

The aim of this study was to evaluate the various histopathological patterns in the endometrial biopsy of patients presenting with abnormal uterine bleeding and to determine the specific pathology in the different age groups.

\section{METHODS}

This was a prospective hospital based study conducted in the Department of Obstetrics and Gynecology in a tertiary care teaching hospital over a period of two years from January 2015 to December 2016. A total of 905 patients presenting to the Gynecology OPD with abnormal uterine bleeding (menorrhagia, polymenorrhoea, irregular bleeding per vaginum, postmenopausal bleeding per vaginum) were included in this study.

A detailed history, systemic and gynecological examination was done for these patients. Baseline investigations and pelvic ultrasound were done. Informed written consent was taken from these patients and they were subjected to a dilatation and curettage in operation theatre. Specimens were sent to pathology department in $10 \%$ formalin. They were studied grossly and multiple sections taken. The specimens were processed in automated tissue processor. Four to six-micron thick paraffin embedded sections were taken and stained by haematoxylin and eosin. The slides were examined under microscope by the pathologist and the various histopathological patterns identified and classified. Data was collected and SPSS software was used for statistical analysis of data.

\section{RESULTS}

Total of 905 patients with Abnormal Uterine Bleeding were included in this study. The age of the patients ranged from 24-74 years.
Table 1: Age group of patients presenting with abnormal uterine bleeding.

\begin{tabular}{|lll|}
\hline Age group & Frequency & Percentage (\%) \\
\hline $20-29$ & 31 & 3.4 \\
\hline $30-39$ & 212 & 23.4 \\
\hline $40-49$ & 495 & 54.7 \\
\hline $50-59$ & 121 & 13.4 \\
\hline Above 60 & 46 & 5.1 \\
\hline total & 905 & 100 \\
\hline
\end{tabular}

Out of the 905 patients with abnormal uterine bleeding, maximum was in the age group 40-49 years- 54.7\% (495 patients) followed by $23.4 \%$ (212 patients) in the age group 30-39 years. $13.4 \%$ (121 patients) were in the age group 50-59 years and $3.4 \%$ (31 Patients) were in the age group 20-29 years. There were around 46 patients $(5.1 \%)$ in the age group above 60 years.

Table 2: Histopathological diagnosis of endometrial biopsy.

\begin{tabular}{|lll|}
\hline HPE Group & Frequency & Percentage \\
\hline $\begin{array}{l}\text { Proliferative } \\
\text { endometrium }\end{array}$ & 428 & 47.3 \\
\hline Secretory endometrium & 146 & 16.1 \\
\hline $\begin{array}{l}\text { Cystoglandular } \\
\text { hyperplasia }\end{array}$ & 84 & 9.3 \\
\hline Cystic atrophy & 75 & 8.3 \\
\hline Disordered proliferation & 56 & 6.2 \\
\hline $\begin{array}{l}\text { Endometrial hyperplasia } \\
\text { without atypia }\end{array}$ & 49 & 5.4 \\
\hline $\begin{array}{l}\text { Glandular hyperplasia } \\
\text { without atypia }\end{array}$ & 17 & 1.9 \\
\hline $\begin{array}{l}\text { Mixed endometrial } \\
\text { pattern }\end{array}$ & 16 & 1.8 \\
\hline Endometrial polyp & 10 & 1.1 \\
\hline $\begin{array}{l}\text { Endometrial hyperplasia } \\
\text { with atypia }\end{array}$ & 7 & 0.8 \\
\hline Chronic endometritis & 6 & 0.7 \\
\hline $\begin{array}{l}\text { Retrogressive cystic } \\
\text { hyperplasia }\end{array}$ & 5 & 0.6 \\
\hline $\begin{array}{l}\text { Glandular hyperplasia } \\
\text { with atypia }\end{array}$ & 2 & 0.2 \\
\hline Endometrial cancer & 2 & 0.2 \\
\hline $\begin{array}{l}\text { Cystoglandular } \\
\text { hyperplasia with atypia }\end{array}$ & 1 & 0.1 \\
\hline Senile cystic hyperplasia & 1 & 905 \\
\hline Total & 500 \\
\hline
\end{tabular}

The most frequent histopathological finding was proliferative endometrium found in 428 patients $(47.3 \%)$ followed by secretory endometrium in 146 patients (16.1\%). Cystoglandular hyperplasia was found in 84 patients $(9.3 \%)$ and cystic atrophy in 75 patients $(8.3 \%)$. Next common was disordered proliferation in 56 patients $(6.2 \%)$ followed by endometrial hyperplasia without atypia in 49 patients $(5.4 \%)$. The other histopathological 
findings included glandular hyperplasia without atypia, mixed endometrial pattern, endometrial hyperplasia with atypia etc.
Out of the 905 patients, 2 patients $(0.2 \%)$ had endometrial cancer. Endometrial polyp was identified in 10 patients $(1.1 \%)$ with abnormal uterine bleeding.

Table 3: Histopathological diagnosis according to age group.

\begin{tabular}{|c|c|c|c|c|c|}
\hline \multirow[b]{2}{*}{ HPE group } & 20-29 years & 30-39 Years & 40-49 Years & 50-59 Years & Above 60 years \\
\hline & $\mathbf{N}(\%)$ & $\mathbf{N}(\%)$ & $\mathbf{N}(\%)$ & $\mathbf{N}(\%)$ & $\mathbf{N}(\%)$ \\
\hline Disordered proliferation & $2(3.6)$ & $14(25)$ & $31(55.4)$ & $8(14.3)$ & $1(1.8)$ \\
\hline Mixed endometrial pattern & $2(12.5)$ & $2(12.5)$ & $11(68.8)$ & $1(6.3)$ & 0 \\
\hline Proliferative endometrium & $11(2.6)$ & $96(22.4)$ & $265(61.9)$ & $50(11.7)$ & $6(1.4)$ \\
\hline Chronic endometritis & 0 & 0 & $4(66.7)$ & $1(16.7)$ & $1(16.7)$ \\
\hline Cystoglandular hyperplasia & $5(6)$ & $19(22.6)$ & $46(54.8)$ & $10(11.9)$ & $4(4.8)$ \\
\hline Secretory endometrium & $9(6.2)$ & $50(34.2)$ & $80(54.8)$ & $6(4.1)$ & $1(0.7)$ \\
\hline Cystic atrophy & 0 & $3(4)$ & 14 (18.7) & $28(37.3)$ & $30(40)$ \\
\hline Retrogressive cystic hyperplasia & 0 & 0 & $1(20)$ & $2(40)$ & $2(40)$ \\
\hline Glandular hyperplasia with atypia & 0 & 0 & $2(100)$ & 0 & 0 \\
\hline Glandular hyperplasia without atypia & $1(5.9)$ & $5(29.4)$ & $8(47.1)$ & $3(17.6)$ & 0 \\
\hline Cystoglandular hyperplasia with atypia & 0 & 0 & $1(100)$ & 0 & 0 \\
\hline Senile cystic hyperplasia & 0 & 0 & 0 & $1(100)$ & 0 \\
\hline Endometrial hyperplasia with atypia & 0 & $3(42.9)$ & $3(42.9)$ & $1(14.3)$ & 0 \\
\hline Endometrial polyp & 0 & $2(20)$ & $6(60)$ & $2(20)$ & 0 \\
\hline Endometrial cancer & 0 & 0 & 0 & $2(100)$ & 0 \\
\hline Endometrial hyperplasia without atypia & $1(2)$ & $18(36.7)$ & $23(46.9)$ & $6(12.2)$ & $1(2)$ \\
\hline Total & $31(3.4)$ & $212(23.4)$ & $495(54.7)$ & $121(13.4)$ & $46(5.1)$ \\
\hline
\end{tabular}

Proliferative endometrium was more common in the age group 40-49 years- 265 patients $(61.9 \%)$, as also disordered proliferation $(55.4 \%)$, secretory endometrium $(54.8 \%)$, cystoglandular hyperplasia (54.8\%) and endometrial hyperplasia $(46.9 \%)$. Cystic atrophy was more common in age group 50-59 years (37.3\%). Retrogressive cystic hyperplasia was also more common in the age group 50-59 years (40\%) compared to other age groups. Both the endometrial cancers were found in the age group 50-59 years.

\section{DISCUSSION}

Abnormal uterine bleeding continues to be one of the most frequently encountered complaints in gynaecology OPD. The frequency of the various causes of abnormal uterine bleeding varies with the age of the patient. Dysfunctional uterine bleeding is a diagnosis of exclusion in which no specific organic cause can be attributed to as the reason. ${ }^{13}$ Abnormal uterine bleeding without structural pathology occurs in reproductive women of all ages but is more common in adolescent and perimenopausal women. ${ }^{14}$ In perimenopausal years, anovulatory cycle is most frequent which in turn causes changes in endometrium which results in irregular bleeding. ${ }^{15}$ In present study, AUB was commonest in the age group 40-49 years (54.7\%). A similar high incidence was reported by Muzaffar $M$ et al, Yusuf NW et al, Doraiswami S et al and Damle P et al while Khan R et al found maximum incidence in the age group 30-39 years. ${ }^{6,7,16-18} \mathrm{We}$ found proliferative endometrium to be the most common histopathological finding in $47.3 \%$ followed by secretory endometrium in $16.1 \%$. Similar finding was found by Dangal G, Bhatta $S$ et al and Khare A et al. ${ }^{14,19,20}$ Khan $S$ et al found proliferative endometrium in $46.6 \%$ of cases while Sheetal et al reported in $42 \%$ of cases. ${ }^{21,22}$ Fakhar $\mathrm{S}$ et al reported a higher incidence of $54 \%$ and Bhosle $\mathrm{A}$ et al reported an incidence of $66.1 \%$ same as Jetley $\mathrm{S}$ et al. ${ }^{23-25}$ Chary $\mathrm{N}$ et al found proliferative endometrium- the most common finding at $60 \%$ followed by secretory endometrium in 17 $\%$ of cases. ${ }^{26}$

Secretory endometrium was the next common finding in present study with 146 patients $(16.1 \%)$. Similar finding of $16.1 \%$ was reported by Bhosle et al while Khan S et al reported $38.4 \%$, Muzaffar $M$ et al $35.4 \%$, Sheetal et al $22 \%$, Fakhar S et al $14 \%$ and Khan R et al $13.7 \% .^{6,7,21-24}$ Abdulla and Bondaji found secretory endometrium to be the most common histopathological diagnosis (24.9\%) followed by proliferative endometrium at $21.7 \% .^{27}$ Present study found Glandular hyperplasia without atypia in $1.9 \%$ cases and with atypia in $0.2 \%$ of cases. Khan S et al found a slightly higher incidence of glandular hyperplasia without atypia in $2.8 \%$ of cases and with atypia in $1 \%$ cases. $^{21}$ Bhatta et al found simple hyperplasia without atypia in $24.6 \%$ patients in the age group 40-49 years while Muzaffar $M$ et al found 
endometrial hyperplasia $(24.7 \%)$ to be the most common lesion followed by chronic nonspecific endometritis $(13 \%))^{7,19}$ Disordered proliferation was found in $6.2 \%$ in our study. A similar incidence of $6.56 \%$ was reported by Bhatta et al while Damle R P et al and Abdulla L S et al observed an incidence of $15.9 \% .^{18,19,27}$ Endometrial polyp was found in $1.1 \%$ cases in present study. A similar incidence was found by Khan $\mathrm{S}$ et al $(0.6 \%)$, Muzaffar $\mathrm{M}$ et al $(1.2 \%)$, Baral R et al $(1.3 \%)^{7,21,28} \mathrm{~A}$ higher incidence was reported by Bhatta $\mathrm{S}$ et al $(2.46 \%)$, Jetley $\mathrm{S}$ et al $(2.7 \%)$, Khan R et al (3.3\%), Sheetal et $\mathrm{al}^{22}(5 \%)$ while a much higher incidence was reported by Mencoglia et al at $20 \% .^{2,6,19,22,25}$ Chronic endometritis in the present study was found in only $0.7 \%$ of patients while it was seen with a higher incidence of $5.68 \%$ in a study by Damle R P et al, $6.4 \%$ by Khare et al, $6.56 \%$ by Bhatta $S$ et al, $9.1 \%$ by Jetley $S$ et al, $13 \%$ by Muzaffar $M$ et al and $20.7 \%$ by MichailG et al. ${ }^{7,18-20,25,29}$ Endometrial cancer was observed in $0.2 \%$ of cases in present study. A similar incidence of $0.4 \%$ was reported by Khan $\mathrm{S}$ et al, Moghal $\mathrm{N}$ et al and Valle $\mathrm{R} F$ et al while it is little higher in studies by Jyotsna et al (1.3\%), Sheetal et al (2\%), and Jong P D (3.3\%). ${ }^{21,22,30-33}$ Damle $\mathrm{RP}$ et al reported a much higher incidence of $9.67 \% .^{18}$ Dilatation and curettage can be a diagnostic as well as therapeutic procedure. The sensitivity of endometrial biopsy for the detection of endometrial abnormalities and for detection of cancer have been reported to be as high as $96 \%$ with a 2-6\% false negative rates. ${ }^{34}$ The main aim of endometrial biopsy is not only to identify causes of abnormal uterine bleeding but also to exclude malignancy. ${ }^{21}$ The principal reason for sampling the endometrium is to evaluate the patient for presence of endometrial hyperplasia and carcinoma and to diagnose acute and chronic endometritis. ${ }^{35}$ Abnormal uterine bleeding may be the symptom of endometrial cancer in 8$50 \%$ of cases. $^{14}$ Management of abnormal uterine bleeding is not complete without tissue diagnosis, especially in perimenopausal and post-menopausal women. $^{28}$

\section{CONCLUSION}

Abnormal uterine bleeding is one of the commonest reasons for women to seek medical help and a major drain on health resources. Histopathological study of the endometrium in these cases reveals a wide variety of abnormalities, evaluation of which will help us to plan for successful management. Endometrial curetting and biopsy are important diagnostic procedures for assessing all cases of abnormal uterine bleeding especially to detect endometrial cancer and endometrial hyperplasia which has very good prognosis if detected and treated early.

\section{Funding: No funding sources} Conflict of interest: None declared

Ethical approval: The study was approved by the Institutional Ethics Committee

\section{REFERENCES}

1. Munro MG. Abnormal uterine bleeding in the reproductive years: Pathogenesis and clinical investigations. J Am Assoc Gynecol laparos. 1999;6:393-416.

2. Mencoglia L, Perino A, Hamou J. Hysteroscopy in perimenopausal and post-menopausal women with abnormal uterine bleeding. J Reprod Med. 1987;32:577-82.

3. Khrouf M, Terras K. Diagnosis and management of formerly called dysfunctional uterine bleeding according to PALM-COEIN FIGO classification and the new guidelines. J Obstet Gynecol India. 2014;64(6):388-93.

4. Kotdawala P, Kotdawala S, Nagar N. Evaluation of endometrium in peri-menopausal abnormal uterine bleeding. J Midlife health. 2013;4(1):16-21.

5. Fraser IS, Sungurtekin U. Defining menstrual disturbances. In Maclean A and O'Brien, P.M.S.(eds) Study Group on Menstrual Disorders. Royal College of Obstetricians and Gynecologist. 2000;141-52.

6. Khan R, Sherwani R, Rana S, Hakim S, Jairajpuri ZS. Clinico-Pathological Patterns in Women with Dysfunctional Uterine Bleeding. Iran $\mathrm{J}$ Pathol. 2016;11(1):20-6.

7. Muzaffar M, Akhtar KAK, Yasmin S, Rahman M, Iqbal W, Khan MA. Menstrual irregularities with excessive blood loss: A Clinico-Pathological Correlation. J Pak Med Assoc. 2005;55:486-9.

8. Brand A, Dubuc-Lissoir J, Ehlen TG, Plante M. Diagnosis of endometrial cancer in women with abnormal vaginal bleeding. J Soc Obstet Gynecol Can. 2000;22:102-4.

9. Stovall TG, Ling FW, Morgan PL. A prospective randomized comparison of the Pipelle endometrial sampling device with the Novak curette. Am J Obstet Gynecol. 1991;165(5,1):1287-90.

10. Goldstein SR, Zeltser L, Horan CK, Snyder JR, Schwatrz LB. Ultrasound based triage for perimenopausal women with abnormal uterine bleeding. Am J Obstet Gynecol. 1997;177:102-8.

11. Clark TJ, Mann CH, Shah N, Khan KS, Song F, Gupta JK. Accuracy of outpatient endometrial biopsy in the diagnosis of endometrial cancer: A Systematic Quantitative review. BJOG. 2002;109:313-21.

12. Dijkhuizen FP, Mol BW, Brolman HA, Heintz AP. The accuracy of endometrial sampling in the diagnosis of patients with endometrial carcinoma and hyperplasia: a meta-analysis. Cancer. 2000;8:176572.

13. Rosai J. Female reproductive system-uterus-corpus. In: Rosai and Ackerman's surgical pathology. 9th edition; Mosby: an imprint of Elsevier, Missouri, 2005;1579-615.

14. Dangal G. A study of endometrium of patients with abnormal uterine bleeding at Chitwan valley. Kathmandu University. Med J. 2003;1:110-2. 
15. Todorovic N, Djordjevic V, Antonijevic S. Results of histopathological findings of endometrial changes in metrorrhagia. Srp Arh Celok Lek. 2002;130:3868.

16. Yusuf NW, Nadeem R, Yusuf AW, Rahman R. Dysfunctional Uterine Bleeding. A retrospective clinicopathological study over 2 years. Pak J Obstet Gynecol.1996;9:27-30.

17. Doraiswami S, Johnson T, Rao S, Rajkumar A, Vijayaraghavan J, Panicker V. Study of endometrial pathology in Abnormal Uterine bleeding. J Obstet Gynecol India. 2011;61(4):426-30.

18. Damle RP, Dravid NV, Suryawanshi KH, Gadre AS, Bagale P S, Ahire N. Clinicopathological spectrum of endometrial changes in peri-menopausal and postmenopausal Abnormal Utrine Bleeding: a 2 year study. J Clin Diagn Res. 2013;7(12):2774-6.

19. Bhatta S, Sinha AK. Histopathological study of endometrium in abnormal uterine bleeding. J Pathol Nepal. 2012;2:297-300.

20. Khare A, Bansal R, Sharma S, Elhence P, Makkar N, Tyagi Y. Morphological spectrum of Endometrium in patients presenting with Dysfunctional Uterine Bleeding. People's Journal of Scientific Research. 2012;5(2):13-6.

21. Khan S, Hameed S, Umber A. Histopathological pattern of Endometrium on Diagnostic D and $\mathrm{C}$ in patients with Abnormal Uterine Bleeding. Annals. 2011;17(2):166-70.

22. Sheetal GP, Bhute SB, Inamdar SA, Acharya NS, Shrivastava DS. Role of diagnostic hysteroscopy in abnormal uterine bleeding and its histopathological correlation. J Endosc Surg. 2009;1(2):98-104.

23. Fakhar S, Saeed G, Khan AH, Alam AY. Validity of pipelle endometrial sampling in patients with abnormal uterine bleeding. Ann Saudi Med. 2008;28(3):188-91.

24. Bhosle A, Fonseca M. Evaluation and Histopathological correlation of Abnormal Uterine Bleeding in Perimenopausal women. Bombay Hospital Journal. 2010;52(1):69-72.

25. Jetley S, Rana S, Jairajpuri ZS. Morphological spectrum of endometrial pathology in middle-aged women with atypical uterine bleeding: A study of 219 cases. J Midlife Health. 2013;4(4):216-20.

26. Chary N, Fathima A, Rani J. Endometrial histopathological changes associated with Dysfunctional Uterine Bleeding. Asian Pac J Health Sci. 2016;3(2):106-9.

27. Abdulla LS, Bondagji NS. Histopathological pattern of Endometrial Sampling performed for Abnormal Uterine Bleeding. Bahrain Medical Bulletin. 2011;33(4):1-6.

28. Baral R, Pudasaini S. Histopathological pattern of endometrial samples in abnormal uterine bleeding. J Pathol Nepal. 2011;1:13-6.

29. Michail G, Karahaliou A, Skiadopoulos S, Kalogeropoulou C, Terzis G, Boniatis I et al. Texture analysis of perimenopausal and post-menopausal endometrial tissue in gray scale transvaginal ultrasonography. Br J Radiol. 2007;80:609-16.

30. Moghal N. Diagnostic value of endometrial curettage in abnormal uterine bleeding- a histopathological study. J Pak Med Assoc. 1997;47:295-9.

31. Valle RF. Hysteroscopic evaluation of patients with abnormal uterine bleeding. Surg Gynecol Obst. 1981;153:521-6.

32. Jyotsana, Manhas K, Sharma S. Role of hysteroscopy and laparoscopy in evaluation of abnormal uterine bleeding. JK Sci. 2004;6:1.

33. Jong PD, Doel F, Falconer A. Outpatient diagnostic hysteroscopy. Br J Obstet Gynecol. 1990;97:2.

34. Albers JR, Hull SK, Wesley RM. Abnormal uterine bleeding. Am Fam Phys. 2004;69:1915-26.

35. Munro MG. Abnormal uterine bleeding in the reproductive years. J Am Assoc Gynecol laparos. 1999;6(4):391-419.

Cite this article as: Gopalan U, Rajendiran S, Karnaboopathy R. Study of endometrial histopathology in women with abnormal uterine bleeding. Int J Reprod Contracept Obstet Gynecol. 2017;6:824-8. 